Article

\title{
The Rule of Ecological Law: The Legal Complement to Degrowth Economics
}

\section{Geoffrey Garver}

McGill University, Montreal, QC, H3A 2T5, Canada; E-Mail: gginmont@sympatico.ca; Tel.: +1-514-582-0929

Received: 13 November 2012; in revised form: 7 January 2013 / Accepted: 14 January 2013 /

Published: 22 January 2013

\begin{abstract}
The rule of ecological law is a fitting complement to degrowth. Planetary boundaries of safe operating space for humanity, along with complementary measures and principles, provide scientific and ethical foundations of the rule of ecological law, which should have several reinforcing features. First, it should recognize humans are part of Earth's life systems. Second, ecological limits must have primacy over social and economic regimes. Third, the rule of ecological law must permeate all areas of law. Fourth, it should focus on radically reducing material and energy throughput. Fifth, it must be global, but distributed, using the principle of subsidiarity. Sixth, it must ensure fair sharing of resources among present and future generations of humans and other life. Seventh, it must be binding and supranational, with supremacy over sub-global legal regimes as necessary. Eighth, it requires a greatly expanded program of research and monitoring. Ninth, it requires precaution about crossing global ecological boundaries. Tenth, it must be adaptive. Although the transition from a growth-insistent economy headed toward ecological collapse to an economy based on the rule of ecological law is elusive, the European Union may be a useful structural model.
\end{abstract}

Keywords: ecological law; planetary boundaries; principle of sustainability; wild law; right relationship; precautionary principle; supranationality; subsidiarity

\section{Introduction}

Apollo empowered Cassandra to know the future in order to seduce her, but when she rejected his love, he cursed her by making it so nobody would believe her. Those revealing "inconvenient truths" [1] about the growing global ecological crisis often face Cassandra's dilemma [2]. 
Scientists are constantly buttressing their consensus [3] that uncompromising ecological boundaries constrain the human economy. Beyond these limits, the climate changes, nutrients overwhelm ecosystems, or biodiversity is lost to such an extreme that the ecological context for the human enterprise irreversibly and catastrophically moves into a new, more perilous state [4]. According to many studies, human society is already crossing these boundaries [4-6]. Yet, these narratives are routinely ignored, resisted or drowned out in public and political discourse, such that legal and other normative regimes that would confront these dangerous trends either fail to emerge or are rejected. Consequently, the global community's de facto governance structure [7] lacks legal and policy regimes that would allow hard ecological truths to carry determinative weight.

The rule of ecological law, operating as a legal complement to ecological or degrowth economics, provides a basis for establishing such regimes. Environmental economics [8,9] attempts to correct environmental market failures by internalizing environmental costs into the prices of goods and services. However, it is incapable of respecting aggregate ecological boundaries within the human-Earth system. The mostly tractionless field [10] of ecological economics [11] responds to this deficiency by recognizing that the functioning of the global ecosystem casts an overarching constraint on the human economy. In law, an analogous deficiency is apparent [12]. Environmental laws typically enshrine in the legal system the reductionist, piecemeal approach of environmental economics, rarely fully adopting a systems perspective. As a result, the envelope of contemporary environmental law is deficient as a means to enclose and regulate the human enterprise within systems-based ecological constraints [13]. Just as ecological economics emerged to address limitations of environmental economics, the rule of ecological law is needed to transcend limitations of contemporary environmental law.

The degrowth movement provides a specific context for the emergence of the rule of ecological law. Degrowth (or "sustainable degrowth") involves "a downscaling of production and consumption that increases human well-being and enhances ecological conditions and equity on the planet" [14]. Degrowth has roots both in ecological economics and in the socio-cultural objections to wealth accumulation and bigness reflected in Schumacher's Small is Beautiful and earlier critiques of "gigantism" [15]. The current degrowth movement gathered steam after the French magazine Silence published special issues on décroissance in February and March 2002. The provocative word intended to shake loose the human imagination from the entrenched idea that the economy must grow for humanity to survive $[15,16]$ has evolved into a collaborative discussion and research agenda for developing "a framework for transformation to a lower and sustainable level of production and consumption" [14]. The redistributive and transitional reforms associated with degrowth start with recognition of global ecological limits and emphasize community involvement, decommodification and decommercialization. Areas of specific focus in the degrowth movement include local economic autonomy, equitable sharing of work and resources, low-impact technologies, a narrow view of private property, food sovereignty and floors and ceilings on income, as well as on monetary reform, trade reform, constraints on advertising and restrictions on harmful technologies $[17,18]$.

Systems-based ecological boundaries that promote the flourishing of life systems provide the base of a structure of ecological law (in the legal sense) that must be respected and enforced to fend off catastrophe and enhance the capacity for life. The looming prospect of transgressing critical ecological points of no return requires the global community to fashion a systems-based legal and institutional 
structure that is built on the foundation of ecological law under an expanded notion of the rule of law. The degrowth movement is well suited to supporting the development of the rule of ecological law.

\section{The Foundations of the Rule of Ecological Law}

The rule of ecological law combines the notion of ecological law with the notion of the rule of law. Use of the term "ecological law" is rare [19,20]. A starting point for understanding how it is intended here is Thomas Berry's ecologically imbued notion of law: "To achieve a viable human-Earth situation, a new jurisprudence must envisage its primary task as that of articulating the conditions for the integral functioning of the Earth process, with special reference to a mutually enhancing human-Earth relationship (...) [T] he land, the water, the air, and the complex of life systems (...) would constitute the integral expression of the Great Commons of the planet Earth to be shared in proportion to need among all members of the Earth community" ([21], p. 61). From Thomas Berry's perspective, "[e]cology is not a part of law; law is an extension of ecology" ([21], p. 61).

David Boyd's notion of "sustainability law" [22], Klaus Bosselmann's similar "principle of sustainability" [23], and Cormac Cullinan's "wild law" [24] all broadly capture Berry's ecological conception of law. Boyd characterizes sustainability law as "a system of laws and policies that facilitate processes, products, and patterns of behaviour which are good for the planet" ([22], p. 365). For Boyd, "sustainability law would focus on transforming the relationship between humans and the natural environment from one based on minimizing harm to one based on maximizing harmony" ([22], pp. 364-365). It "would be firmly rooted in science and the laws of nature, beginning with a clear understanding of the laws of thermodynamics and explicit recognition of the biophysical limits of the planet Earth" ([22], pp. 364-365).

Bosselmann insists that respecting and maintaining the Earth's ecological integrity are at the core of sustainability [23,25]. Emphasizing ecological integrity is consistent with its treatment as a fundamental ethical principle [26]. With this grounding, "sustainability has the historical, conceptual and ethical quality typical for a fundamental principle of law," ([23], p. 4) on the same order as foundational principles like equality, justice and freedom. The principle of sustainability implies a "duty to protect and restore the integrity of the Earth's ecological systems" ([23], p. 53). In Bosselmann's view, the Earth Charter, with its emphasis on the interdependence of all life forms, the value of all living things regardless of their value to humans, and the dignity and potential of human beings, is the most profound current expression of the principle of sustainability ([23], pp. 73-75).

As conceived by Cullinan, "wild law" is built on the premise that legal structures should reflect the functioning of the systems that they purport to govern. Thus, wild law fundamentally takes a biocentric or Earth-centered approach, in contrast to human-centered environmental law that, at best, tries to deduce an accurate price for natural systems within an economics driven by human preferences. Cullinan explicitly aims to build on the work of Berry, asserting that "[r]eforming national legislation and entering into new international agreements will be insufficient unless these are done on the basis of a new understanding that the essential purpose of human governance systems should be to support people to play a mutually enhancing role within the community of life on Earth" ([24], p. 29) (emphasis in original). 
Boyd's sustainability law, Bosselmann's principle of sustainability and Cullinan's wild law all recognize the essential primacy of ecological integrity. The term "ecological law" emphasizes this primacy by making clear that global ecological limits constrain the economic and social spheres that are usually associated, along with environmental concerns, with "sustainability"-often in a confusing way. Unlike many notions of sustainability, especially in the context of the Rio Principles [27] as reconfirmed at the Rio +20 conference on sustainable development [28], the rule of ecological law calls into question the current insistence on perpetual economic growth.

The "rule of law" as used here conveys dual notions. First, legal institutions and norms, from the global to the local level, should provide a coherent, reliable, fair and just framework for managing human affairs. Second, the scientific laws that govern how the Earth works necessarily constrain the legal architecture for ecological law. The United Nations Security Council captures the essence of the first of these notions in its description of the rule of law as requiring "measures to ensure adherence to the principles of supremacy of law, equality before the law, accountability to the law, fairness in the application of the law, separation of powers, participation in decision-making, legal certainty, avoidance of arbitrariness and procedural and legal transparency" [29]. The second notion derives from the emphasis on the rule of ecological law, which clarifies that the norms and laws of concern are founded not only in legal principles but also in planetary boundaries and other expressions of the uncompromising ecological limits of the life support capacity of the Earth. In this vein, "the 'rule of law' means that global regulatory limits required to meet ecological limits and ensure fair sharing of the earth's bounty must be respected" ([7], p. 135).

Although ecological law is firmly grounded in the science of how the Earth works and of complex systems thresholds in the global ecosystem, science alone cannot determine its elements. The laws of thermodynamics and the science of ecology, both central to the scientific understandings on which ecological economics and ecological law are built, cannot simply be plugged in to make the human-Earth relationship right. Both a thriving tropical forest and a lifeless toxic waste dump have their own ecology, and both obey the laws of thermodynamics. The same holds true for an Earth with or without human survival. But, neither the degrowth movement nor ecological law is indifferent to those circumstances, or to the human place in them. Rather, both ecological law and degrowth derive from a fundamental normative choice to manage the human enterprise so as to sustain circumstances to which ecology, thermodynamics and the other sciences will apply in ways that allow the human-Earth relationship to thrive.

An international team of researchers has proposed planetary boundaries [4] that, along with related ecological indicators, help describe those circumstances, providing a key part of the basis for the normative decisions inherent in ecological law. Planetary boundaries are normative, interrelated global ecological systems limits of "safe operating space" for humanity, beyond which humans face an unacceptable "risk of deleterious or even catastrophic environmental change at continental to global scales" ([4], p. 2). The nine proposed interacting boundaries are based on climate change, ocean acidification, stratospheric ozone depletion, atmospheric aerosol loading, land use, freshwater use, chemical pollution, biodiversity loss and nutrient cycles. Although the proposed boundaries generally refer to limits or systems thresholds associated with stocks, as with the amount of carbon dioxide in the atmosphere, they are amenable to translation into limits on flows, such as limits on the rate at which greenhouse gases are emitted into the atmosphere. The boundaries 
are "non-negotiable," ([4], p. 4) such that "[t]he thresholds in key Earth System processes exist irrespective of peoples' preferences, values or compromises based on political and socioeconomic feasibility, such as expectations of technological breakthroughs and fluctuations in economic growth" ([4], p. 7). Planetary boundaries researchers posit that planetary boundaries indicate the need for "novel and adaptive governance approaches at global, regional and local scales" ([4], p. 28). The essential primacy of the boundaries underscores this call for innovation and adaptiveness.

Social, political or cultural concerns, grounded in ethics and justice that transcend the notions of safety and survival inherent in the planetary boundaries concept, provide additional grounds for making normative decisions consistent with the rule of ecological law. The notion of "right relationship" reflects these other concerns [7]. Right relationship derives from Aldo Leopold's land ethic: "A thing is right when it tends to preserve the integrity, stability, and beauty of the biotic community" ([30], pp. 224-225) [31]. It serves as a "guidance system for functioning in harmony with scientific reality and enduring ethical traditions" ([7], p. 4). Right relationship reflects ecological limits but also "include[s] the fair sharing of the earth's life support capacities with all of life's commonwealth" ([7], p. 17). An economy built on right relationship aims to "provid[e] rich and fulfilling lives for both individuals and communities, but without pushing toward extreme wealth and advantages that destroy social and ecological well-being" ([7], p. 26. Thus, right relationship seeks a positive, life-enhancing human-Earth relationship, not merely a safe and survivable one. As well, it forges a link between the biophysical constraints that underlie the planetary boundaries framework and the human and ecological solidarity and sense of community that (along with a strong notion of ecological limits) are integral to degrowth.

\section{The Shortcomings of Contemporary Environmental Law}

The planetary boundaries proposal, supplemented by complementary measures and ongoing refinements, is powerful because of its potential to provide a comprehensive framework for adaptive legal and policy mechanisms based on a scientific, ecological approach from the global to the local level. The power of this framework resides in its commitment to a systems-based approach that depends on the best possible understanding of human-Earth dynamics and feedbacks while acknowledging the irreducible scientific uncertainty that makes it impossible to predict the often non-linear and chaotic behaviour of Earth's life systems. The viability of some proposed boundaries, such as those related to nutrient loading and biodiversity, has been questioned because they are difficult to conceptualize or model at the global level, as opposed to regionally or locally [32]. However, others, in particular the boundary for climate change, are clearly of global significance, and the boundary categories taken together reflect a comprehensive set of interacting systems features of the global ecosystem that frame the ecological contours of the human prospect. Contemporary environmental law lacks this holistic foundation.

A key flaw of contemporary environmental law is its reductionist tendency to focus on environmental problems as discrete and isolated, which impedes the full integration of a systems-based ecological approach into the entire legal infrastructure [22]. Most environmental laws and regulations adopted in the United States and elsewhere since the 1970s miss the forest of aggregate systems impacts for the trees of smokestacks and sewage pipes [13,33]. They have reduced some of the most 
obvious environmental pollutants in light of known harmful effects (albeit too often allowing pollution despite serious uncertainty as to risks), but they have not evolved to address effectively the cumulative impacts and scale effects tied to the growing material and energy throughput that has accompanied economic growth [34].

A second flaw is the tendency in environmental law, as with environmental economics, to favour monetization as the way to normalize social preferences and to regulate the relationship between environmental problems and the development pressures that create them. Environmental law relies too heavily on assessments of monetized costs and benefits and an enduring allegiance to a reactive, non-precautionary approach that gives primacy to economic constraints instead of ecological ones $[13,22]$. Compared to contemporary environmental law, ecological law would place ecological constraints on property and cordon off the sphere of market exchanges based on abstract monetary units to a considerably greater extent [7].

A holistic approach has not been entirely absent from contemporary environmental law. As the environmental awakening emerged in the 1960s and 1970s, holistic thinkers helped bring an ecological perspective into the law [35]. Kenneth Boulding offered the powerful notion of Earth as a finite spaceship; Aldo Leopold's land ethic was revived; and Joseph Sax's public trust theory of environmental protection had wide influence on environmental policy [36]. However, the "deep ecology" [37], public trust and Leopoldian elements of the environmental awakening gave way to the economically driven ideology of the 1980s, and the economic glaze over environmental law has only hardened since [25,33].

The system-based mechanisms in contemporary environmental law are generally weak, limited or subservient to economic and political interests. For example, environmental impact assessment laws requiring analysis of the effects of economic activity on ecosystems are, by and large, procedural only [38], promoting awareness, but rarely if ever binding, concrete action to protect ecosystems $[39,40]$. Three more specific examples illustrate additional shortcomings: Total Maximum Daily Loads (TMDLs) under the United States' Clean Water Act [41-50]; critical loads and levels for air pollutants under the 1979 Convention on Long-range Transboundary Air Pollution (LRTAP) [51]; and the successful, but exceptional, regime to control ozone-depleting substances under the Montreal Protocol.

The Clean Water Act requires States to establish water quality standards for ambient water quality, taking into consideration different uses and, to an extent, the ecological impacts of pollutants on aquatic ecosystems [52]. States must identify waters in which any applicable water quality standard is not being met, and then calculate the total maximum daily loads of problem pollutants to those waters from point, non-point and natural sources [53]. TMDLs provide a non-binding basis for tightening point-source permits and exploring ways to control non-point-sources like urban or agricultural runoff, which the Clean Water Act regulates weakly-even though they are often the greatest source of pollution [54,55].

Because TMDLs establish the aggregate loadings needed to maintain water quality at levels established in part according to ecological criteria [56], they are a possible proxy for an ecological system boundary. They have a fairly direct relationship to the planetary boundaries for chemical pollution and nutrient fluxes [4]. Nonetheless, State and federal regulators essentially ignored the mandate to establish TMDLs for almost twenty years, until spurred by litigation to do so in 
the 1990s [57]. Now that the TMDL program has slowly come to life, its functional limitations are becoming apparent. Most critically, States are not required to implement TMDLs or to apply them in a binding manner to non-point sources [58]. In 2003, the Bush Administration withdrew a Clinton Administration TMDL rule that required States to develop detailed implementation plans and schedules for actions to reduce point and non-point pollutant loadings of impaired waters [59]. Not surprisingly, many water bodies in the United States still fail to meet water quality standards, often because of non-point-source pollution [60].

The European critical loads and levels approach was developed under the United Nations Economic Commission for the LRTAP. Critical levels are "concentrations of pollutants in the atmosphere above which direct adverse effects on receptors, such as human beings, plants, ecosystems or materials, may occur according to present knowledge" ([55], p. III-1). Critical load is a "quantitative estimate of an exposure to one or more pollutants below which significant harmful effects on specified sensitive elements of the environment do not occur according to present knowledge" ([55], p. V-1). Systems modeling and mapping are used to estimate the emissions reductions and allocations that are needed to keep levels of individual pollutants, or pollutants in combination, below systems thresholds reflected in critical loads and levels [55].

Because technological and economic factors dominate, exceedances of critical loads and levels are still widespread in Europe, even if decreasing [61,62]. The initial levels of emissions reductions required under the LRTAP were based solely on technical and economic considerations, without taking into account the connection between exceedances and loads [55]. In the next set of protocols, environmental considerations carried more weight, but attaining critical loads for all ecosystems in Europe was considered infeasible because of technical and economic considerations [55]. Gradual attainment of critical loads and levels remains only a long-term objective; complete elimination of exceedances is not necessarily anticipated, and in some cases is considered impossible [63,64].

The equivalent program in the United States is the cap-and-trade mechanism under 1990 amendments to the United States Clean Air Act [65]. A gradually diminishing cap on emissions of sulphur dioxide from all electric utilities and other sources was established, an initial set of emissions quotas was allocated to the sources, and a market was created to allow sources to buy and sell the right to emit sulphur dioxide within the overall cap. Although Congress recognized the ecosystem harm that acid rain caused both nationally and internationally [66], the acid rain program does not link pollutant reductions to a clear ecological objective for the affected ecosystems, even if some protection of those ecosystems was anticipated. The program's parameters derive primarily from political and economic considerations [67,68], and even greater reductions in sulphur dioxide emissions may have been achieved by continuing command-and-control provisions that the cap-and-trade program effectively repealed, albeit at greater cost to the regulated industry [69]. Although the Acid Rain program is widely depicted as a success, it has reduced sulphur dioxide emissions less than its European counterpart, and serious ecosystem damage from acid rain persists [70-72].

The most prominent example of mostly successful ecosystem-based regulation is the international regime for controlling substances that deplete stratospheric ozone. The Montreal Protocol was adopted in 1987, two years after the ozone hole over Antarctica was discovered [73]. The agreement sets forth a mandatory schedule of reductions for the production and consumption of ozone-depleting substances, 
along with a process for ongoing monitoring and adjustments. The signatory parties have tightened restrictions six times, both by decreasing the allowable production and consumption of ozone-depleting substances and by bringing additional substances under the Protocol, with exceptions for "essential uses" and attenuated control schedules for developing countries [74-78].

The Montreal Protocol has dramatically reduced the production and consumption of ozone-depleting substances [79,80]. A 2007 report indicated that, if compliance with the Protocol continued, the levels of ozone in the stratosphere would return to their pre-1980 levels, when no hole in the ozone layer existed, by 2050 at mid-latitudes and a decade or two later at the poles [81]. Because of this apparent progress, protection of stratospheric ozone is mostly [82-84] considered to be "a good example where concerted human effort and wise decision making seem to have enabled us to stay within a planetary boundary" ([4], p. 15). However, the planetary boundaries are interrelated, and some fear that global warming could impede recovery of the ozone layer [85].

Although scientific consensus on the impacts of ozone-depleting substances was quite strong, it was not absolute, and the Montreal Protocol is therefore a relatively successful application of the precautionary principle to avoid catastrophic systemic effects on human health and the global environment [84]. The Protocol's relative success has also been attributed to the elaboration of separate tracks for developed and developing countries [86], and to funding capacity building and technology transfer in developing countries [82]. For several reasons, however, the success of the Montreal Protocol has not been repeated with other global problems like climate change-for which the international community recognized in the 2009 Copenhagen Accord and the 2010 Cancun Agreements, but has utterly failed to take steps to implement, a human-caused temperature rise of two degrees Celsius as a scientifically derived, system-based limit. Compared to other problems, the science on the impacts of ozone-depleting substances was relatively uncontroversial, the public was largely in favour of action, the number of producers of ozone-depleting substances was small, and substitutes were readily apparent and feasible [34,83]. Thus, the Montreal Protocol did not significantly challenge the primacy of economic and technological constraints over ecological ones.

\section{Applying Lessons from Existing Mechanisms in Formulating Ecological Law}

The TMDL programme, the critical loads and levels approach under the LRTAP, and the Montreal Protocol are among the most promising of existing environmental mechanisms in that they pay at least some attention to systems limits. The Montreal Protocol has been successful in ways that other system-based mechanisms have not. Although at least some of those other mechanisms have identified thresholds on the tolerance of receptor systems to the effects of pollutants, they have not yielded effective controls on the industrial and other processes that cause those effects because of the primacy of technological and economic factors.

The context and necessity for weighing the aggregate impact of economic activities against unyielding global ecological limits under the rule of ecological law is becoming increasingly clear. A 2008 study on nitrogen-based pollutants under the LRTAP noted that abatement of emissions should ultimately address global problems like climate change and biodiversity loss [62]. In other words, the backdrop for a review of international, national or regional pollution control policy regimes is the planetary boundaries (or like indicators), and particularly the ones that planetary boundaries 
researchers warn we have already crossed: nitrogen fluxes, phosphorus loading, climate change and biodiversity $[4,87]$.

The example of the Montreal Protocol demonstrates the possibility of collectively tackling a global, systemic environmental problem, with a differentiated system of responsibility for countries at different stages of economic development and well-being, and an adherence to the precautionary principle. This record of performance provides lessons for a more generalized approach, particularly in regard to precaution, fairness and supranationality. The rule of ecological law offers a framework for allowing these lessons to take root with respect to a full spectrum of planetary boundaries.

\section{Ten Core Features of the Rule of Ecological Law}

Systems-based legal mechanisms that contain human use of the ecosphere within ecological limits and fulfill a vision of a more ecological, just and peaceful world will need a place to live. The architecture for the rule of ecological law must include an institutional structure consisting of "a set of principles, rules, norms and procedures" along with physical and organizational infrastructure [88]. The institutional challenge is enormous, because the architecture must encompass an integrated system from the global to the local level, addressing complex dynamics of temporal and spatial scale (including interrelationships that cut across those scales) and also shifting the current primacy given to creation of monetary wealth to considerations of the ecological limitations of the economy. The existing global complex of environmental institutions, from the global to the local level, has hardly prevented global ecological threats from worsening, and they seem unlikely to do so without radical reform.

Tseming Yang and Robert Percival describe the features of an emerging field of "global" environmental law that transcends traditional understandings of international, domestic and local law [89]. They describe global environmental law as

the set of legal principles developed by national, international, and transnational environmental regulatory systems to protect the environment and manage natural resources (...) It includes: (1) public international environmental law, commonly used to refer to the set of treaties and customary international legal principles governing the relations between nations; (2) national environmental law, which describes the principles used by national governments to regulate the behaviour of private individuals, organizations, and subnational governmental entities within their borders; and

(3) transnational law, which describes the set of legal principles used to regulate the crossborder relationships between private individuals and organizations ([89], pp. 616-617).

Prominent in this notion of global environmental law are the precautionary principle and the "polluter pays" principle, along with widespread use of environmental impact assessments and permit systems for polluters, all of which support the central substantive goals of protecting human health and the integrity of ecosystems [89].

The global complex of hard and soft legal mechanisms that Yang and Percival describe reflects a kind of schizophrenia in the law regarding the most pressing global ecological challenges: an increasingly interlinked network of approaches for dealing with some aspects of environmental 
stress on one hand, and an unrelenting failure to deal with the most momentous, aggregate ecological problems on the other. The principal problem is that global environmental law is essentially the handmaiden of growth-driven economic globalization. Yang and Percival present global environmental law as a counterpart to sustained economic growth, which they appear to endorse without contemplating whether such growth is tenable in light of the growing global ecological crisis ([89], p. 616). In noting "a growing convergence around a few principal approaches to environmental regulation," ([89], p. 616), they fail to ask whether those approaches are capable of reining in the enormous drive to unleash financial capital "to mobilize global resources as fodder for industrial metabolism," ([61], p. 220), with adequate attention to how the aggregate scale of the economy measures up against global ecological limits.

A legal regime that accords with ecological economics, degrowth and global ecological boundaries will undoubtedly impose on human activities limitations that do not exist under the current legal regimes in most if not all of the developed world. A system in which ecological restraints envelope the economy requires the collectivity of economic actors to limit their choices so that, taken together, they respect those ecological limits. Yet, in market economies, the freedom to spend on activities and maximize personal wealth, often regardless of their ecological costs, is paramount [90]. The reward that a well compensated person expects is not just money, but more specifically what that money can purchase: often, one or more large homes, jet-fuelled vacations in far-off places, and a host of other material and energy intensive luxuries. This legally protected consumption, rooted in strong notions of property rights and personal freedom, exacts ecological costs that are collectively shared and often incremental, diffuse and delayed and consequently mostly external to the economic and legal infrastructure. Analyses of the trade flows of material and energy resources indicate that their consumption in high-income countries contributes significantly to biodiversity losses and other ecological harms that are most severe in low- and middle-income countries [91,92]. The current legal and institutional infrastructure does little to address such ecological stresses. Moreover, within this infrastructure, intellectual property rights may well impede the flow of information that could lead to or expedite solutions to ecological problems [93].

The rule of ecological law must overcome the limitations of contemporary environmental law, including its reflection in Yang and Percival's global environmental law. To do so, it should include at least the ten following mutually reinforcing features.

First, and most fundamentally, the rule of ecological law recognizes that humans are part of Earth's life systems, not separate from it. Berry put it this way: "We might begin by recognizing that the life community, the community of all living species, including the human, is the greater reality and the greater value. The primary concern of the human community must be the preservation and enhancement of this comprehensive community, even for the sake of its own survival” ([21], p. 4). Indeed, as discussed above, the rule of ecological law should go beyond survival and promote the flourishing of the commonwealth of life [4]. The rule of ecological law calls for a revival of the notions of deep ecology and Leopoldian ethics that ceded to a more instrumentalist view of non-human life and life systems at the birth of contemporary environmental law. A leading expression of the oneness of Earth's commonwealth of life is the Earth Charter, which states: 
To move forward we must recognize that in the midst of a magnificent diversity of cultures and life forms we are one human family and one Earth community with a common destiny. We must join together to bring forth a sustainable global society founded on respect for nature, universal human rights, economic justice, and a culture of peace. Towards this end, it is imperative that we, the peoples of Earth, declare our responsibility to one another, to the greater community of life, and to future generations.

Second, legal regimes must be constrained by ecological considerations necessary to avoid catastrophic outcomes and promote the enhancement of life, with the socio-economic spheres fully contained within these ecological constraints. This core notion of ecological economics applies equally to the rule of ecological law. The planetary boundaries framework and similar normative concepts, like ecological footprint, are based on this recognition of the primacy of ecological limits. In suggesting the need for "novel and adaptive governance approaches at global, regional and local levels" ([4], p. 28), based on the boundaries framework, planetary boundaries researchers are in essence calling for the development of a comprehensive system of ecological law. The planetary boundaries framework also makes clear that this approach must be systems-based, which means that ecological law must track the interactive dynamics among the boundaries and the feedbacks, thresholds, non-linearity and other characteristics of the global social-ecological system. This systems-based approach must pay attention to both stocks (for example, the total amount of greenhouse gases in the atmosphere) and flows (for example, the rates at which greenhouse gases are added to a extracted from the atmosphere) that are related to maintenance of Earth's life support capacity. Further, to respect ecological constraints, ecological restoration must be applied where ecological limits have already been exceeded.

Third, the rule of ecological law must permeate legal regimes and other disciplines like economics in a systemic, integrated way, and not be seen as a specialty area of the law that applies to isolated problems. This feature, which follows implicitly from the second feature, has profound implications. It means that constitutional law, contracts law, torts law, property law, trade law, law related to corporations and finance and all other areas of the law must be adjusted so as to recognize the primacy of ecological limits. National constitutions that recognize the rights of nature, such as those of Ecuador and Bolivia, may be a step toward the sweeping reform of the law that this feature implies. However, the longer that those fairly recent constitutional provisions remain in place without being interpreted so as to trigger an integration of the primacy of ecological limits into the law, the less likely they will ever do so. The transition toward fuller integration of an ecological economics perspective into the law and other disciplines will sharpen the focus on the many wrenching questions and tradeoffs that will have to be addressed in shaping social, political and cultural institutions and practices so that they maintain human society within safe operating space. For example, what are the prospects for proposals for feeding a world likely to include around nine billion people by 2050 with fewer environmental impacts [94], given the heavy dependence of modern agricultural on artificial fertilizers and fossil fuels?

Fourth, because the human enterprise has already transgressed global ecological limits, the legal regime should support a radical re-focusing of the economy on reduction of its throughput of material and energy. This feature captures most directly one of the central ideas of the degrowth movement: 
its recognition that the market cannot be expected to constrain material and energy throughput in the economy on its own. Rather, a broad cultural values shift, reflected in the law, is needed toward an economy that "takes no more than it needs and uses or more than it must [and] provide[s] only as much wealth as is needed for dignified, secure living" ([4], p. 36). As well, because government standards or policies have been necessary historically to protect the environment from market forces, they-or other reliable and enduring means to ensure widespread changes in practice-must help drive the uptake of technology that improves resource productivity, such as zero-emissions or carbon neutral technologies. Aggregrate metrics of social metabolism, such as material and energy flow accounting, measures of human appropriation of net primary production and ecological footprinting, should play an increasing role in tracking and reducing material and energy throughput. Correlating these metrics with pressures on planetary boundaries can help identify the economic sectors and activities for which laws and policies are most needed to promote reductions in material and energy throughput. Explicit care is needed to avoid the rebound effect, by which more efficient use of material and energy leads to overall increases in their use [95]. Additional legal and policy mechanisms are needed for directing the use of any economic gains associated with efficiency to even further reduction of the throughput of material and energy in the economy, so as to maintain sufficient resource stocks and waste processing capacity to avoid running down the Earth's ecological base. Where efficiency gains are insufficient to decrease aggregate use of materials and energy or production of waste, the remaining reduction in the impacts that are pushing the economy past ecological boundaries must come from widespread cultural shifts that simply eliminate production and consumption.

Fifth, the rule of ecological law must be global, but distributed fairly using principles of proportionality and subsidiarity, with protection of the global commons and public goods paramount, and with constraints on property rights and individual choice as needed to keep the economy within ecological limits. A central challenge is to develop legal mechanisms for distributing global limits on the global aggregates of material and energy resources that the economy consumes and the wastes it produces down to the local level, while maintaining local autonomy and eco-cultural identity and ensuring that localities or regions do not unfairly reap benefits that impose costs globally or across political boundaries. If implemented on a global level and in a way that accounts for the multiscalar and uncertainty-laden nature of global ecological change [96], the principles of subsidiarity and proportionality that form part of the bedrock of the European Union treaties could provide strong structural support for such distribution. Subsidiarity favours intervention at the level at which it will be most effective for achieving policy objectives [97], and proportionality means that government at all levels much have sufficient authority and capacity for achieving those objectives [7]. This architecture of distribution should also incorporate legal and policy mechanisms for enabling all humans and other living beings to flourish, built on principles of intragenerational, intergenerational and interspecies fairness [7].

Sixth, the rule of ecological law must ensure fair sharing of resources among present and future generations of humans and other life forms. A central feature of the globally dominant economic and legal paradigm is its protection of market freedoms and property rights with a view to maximizing economic efficiency and maintaining perpetual economic growth, on the assumption that doing so will both allow for environmental protection and provide the greatest welfare for the greatest number of people $[9,26]$. The purported fairness objective is that all humans (but not other species) should have 
an equal possibility to consume and seek wealth, but fairness is rarely assessed in relation to initial endowments that result from inheritances, luck and actual outcomes [7]. Under the rule of ecological law, individual humans and artificial entities like corporations would be considered interrelational beings in a shared ecological context, and not as free agents whose quest to maximize abstract monetary wealth that can be converted into consumptive and waste-producing activities is given priority. The notion of relationship within a shared commonwealth of life provides the basis for fairness and distribution. Herman Daly provides a sound rule of fairness in proposing that "[w]e should strive for sufficient per capita wealth-efficiently maintained and allocated, and equitably distributed - for the maximum number of people that can be sustained over time under these conditions" ([98], p. 220). The focus on sufficient as opposed to maximum wealth implies a limit on inequality of wealth, and that it is possible to be too rich - with the limits established so as to allow for the flourishing of non-human species and ecological restoration. Indeed, the excess wealth that has driven the current situation of ecological overshoot exists primarily in developed countries, and the Rio principle of common but differentiated responsibilities implies a need to adjust future entitlements to draw from Earth's limited life support capacity by taking into account historical contributions to ecological problems. A tall order for the rule of ecological law is the development of ways to account for these historical patterns, as well as for trade patterns by which goods and services embody ecological impacts that occur at great distances away, in assigning responsibilities for staying within global ecological boundaries. For example, one intriguing proposal is to apportion net greenhouse gas emissions reductions such that by the end of the phase-out period, half of total historic emissions will have come from Kyoto Annex B (developed) countries, and half from non-Annex B (developing) countries [99].

Seventh, the rule of ecological law must be binding (de jure or de facto) and supranational, with supremacy over sub-global legal regimes as necessary. Supranational authority is a necessary complement to subsidiarity and proportionality, because planetary ecological boundaries require global legal and policy mechanisms, and therefore must have supreme, binding authority in national and sub-national systems. By allowing ecological impacts and their drivers to be considered collectively, supranational authority provides a way to reconcile a preference for establishing policy at the local level with the reality that localities are never immune from impacts that arise from away or able to avoid causing impacts that reach other localities or are global in nature. The emergence of supranational law in Europe in the environmental domain and others as European treaty law evolved illustrates the logic of imposing supranational law for supranational problems, just as the establishment in the United States of strong federal environmental laws in the 1970s responded to the inadequacy of sub-national environmental regimes. Both examples illustrate as well the need for a well-functioning judicial authority, or its equivalent, to enforce the binding nature of supranational rules. To be sure, relying on supranational authority to regulate the relationship between localities horizontally with each other and vertically with other levels of political order may face cogent resistance within the degrowth movement. In general, the degrowth community tends to doubt the possibility of true democracy at levels of political organization higher than the local, and therefore rejects world government in favour of a "democracy of cultures [involving] minimal arbitration between sovereign polities with highly divergent systems" [100]. However, the dynamics and interregional interdependencies of biogeochemical, geologic, hydrologic, climatic, atmospheric and other processes prevent any sub-global region or locality from being isolated from the rest of the integrated global ecosystem, as a 
study that detected fingerprinted dioxins from sources in Mexico, the United States and southern Canada in mothers' milk and other receptors in Inuit communities in Nunavut illustrated starkly [101]. Even the minimum level of supranational rules needed to address transboundary and global interrelationships effectively is likely quite significant.

Eighth, a greatly expanded program of research and monitoring for improved understanding and continual adjustment of ecological boundaries and means for respecting them is needed to support the rule of ecological law, globally, regionally and locally. The rule of ecological law will depend on a deep scientific understanding of the global ecosystem, its subcomponents, and their relationship with the human sphere, but with acknowledgment that this understanding cannot avoid the irreducible uncertainty in how the global ecosystem behaves. The areas in which greatly expanded research is needed fall into two categories. An adequate system of global governance will require first, more research into the Earth's life systems, their systems behaviour and thresholds, and the impacts of the human enterprise on those systems; and second, ongoing research into the governance structures that are most appropriate for the rule of ecological law. To complement this expanded program of research and monitoring, a comprehensive reform of educational systems will be needed, both to deepen understanding of the primacy of ecological limits in the human prospect and to prepare new generations of scientists and decision makers of all kinds to collaborate on approaches that implement the rule of ecological law.

Ninth, the rule of ecological law requires precaution about crossing planetary boundaries, with margins of safety to ensure both that the boundaries are respected from the global to the local level, and that Earth's life systems have the capacity to thrive. The original set of proposed planetary boundaries incorporate this precautionary approach in that the boundaries are set at the most conservative end of ranges of uncertainty as to where the threshold falls between safe and catastrophic conditions for each sub-component of the global ecosystem [4]. For example, for climate change the boundary is set at an atmospheric carbon dioxide concentration $350 \mathrm{ppm}$ and net radiative forcing of +1 watt per meter squared, with a zone of uncertainty of 350-550 ppm for atmospheric carbon dioxide and of +1 to +1.5 watt per meter squared for net radiative forcing. Thus, catastrophe is part of the definition of the boundaries, and they reflect normative choices of acceptable risk in the face of uncertainty regarding when human impacts on ecosystems become globally catastrophic. Arguments that potential economic catastrophes are at least as important as catastrophes associated with crossing the planetary boundaries, in particular the climate change boundary [84], typically ignore the possibility of alternative economic scenarios that might avoid economic catastrophe, such as degrowth scenarios and other innovations in access to and distribution of the means of well being. A precautionary approach under the rule of ecological law must avoid the intermingling of incommensurable values and risks that such comparisons entail, and it must acknowledge the primary degree of caution that is due to uncertainty regarding the risk of systemic ecological catastrophes.

Last, ecological law must be adaptive, for two main reasons. First, in order to exercise caution about crossing planetary and sub-global ecological boundaries, ecological constraints on the human enterprise must be integrated into the global legal and policy structure despite uncertainties, which will persist in some form or another. An adaptive approach allows mechanisms to be put in place to fend off catastrophe and adjusted as research and experience fill gaps in knowledge about Earth systems and 
about governance of the human-Earth relationship. The adaptiveness called for applies both to the response to evolving scientific understandings and to the mechanisms and institutional arrangements in which to apply them. Among other things, an adaptive approach much consistently update and refine the establishment and fulfillment of common but differentiated responsibilities of developed and developing countries. Second, adaptation is needed in recognition of the non-equilibrium nature of ecosystems. A key development in the science of ecology in the last few decades has been the switch from an equilibrium view of nature, in which ecosystems were assumed to have an ideal natural state, to a non-equilibrium view, in which ecosystems are now seen as constantly evolving, often in stochastic and non-linear ways [102].

\section{Conclusions: The Emergence of the Rule of Ecological Law}

The call for the rule of ecological law emerges from the tension between opposing narratives of impossibility. On the one hand is the seeming impossibility of ending the current intransigent commitment to infinite economic growth, the primacy of short-term economic interests and the overriding belief in technological solutions to ecological challenges. Contemporary environmental law is embedded firmly in this narrative. On the other hand are the systemic impossibilities and long-term catastrophic socio-ecological consequences if the economy grows infinitely and economic and political trade-offs continue to outweigh non-negotiable ecological limits. This narrative is at the heart of the degrowth movement. The growing tension between these opposing narratives creates an opportunity for transformation of humanity's normative paradigms, for further evolution and growing influence of the degrowth movement and for a more comprehensive development of the preliminary framework set out here. If the researchers who developed the uncompromising planetary boundaries framework and other expressions of the global ecological limits that humanity is currently overshooting are right, the first set of impossibilities must give way to the second - and the rule of ecological law should emerge as a solution that will break Cassandra's curse.

\section{Acknowledgments}

This article is based on reference [103] and is an extended adaptation of reference [104].

\section{Conflict of Interest}

The author declares no conflict of interest.

\section{References and Notes}

1. Gore, A., Jr. An Inconvenient Truth: The Planetary Emergency of Global Warming and What We Can Do About It; Rodale: New York, NY, USA, 2006.

2. Atkisson, A. Believing Cassandra: An Optimist Looks at a Pessimist's World; Chelsea Green: White River Junction, VT, USA, 1999.

3. Oreskes, N.; Conway, E.M. Merchants of Doubt; Bloomsbury Press: New York, NY, USA, 2010.

4. Rockström, J.; Steffen, W.; Noone, K.; Persson, Å.; Chapin, F.S.; Lambin, E.; Lenton, T.M.; Scheffer, M.; Folke, C.; Schellnhuber, H.; et al. Planetary boundaries: Exploring the safe 
operating space for humanity. Ecol. Soc. 2009, 6, article 32. Available online: www.ecologyandsociety.org/vol14/iss2/art32/ (accessed on 29 August 2011).

5. The Living Planet Report; Hails, C., Humphrey, S., Loh, J., Goldfinger, S., Eds.; WWF International: Gland, Switzerland, 2008.

6. Speth, J.G. The Bridge at the Edge of the World; Yale University Press: New Haven, CT, USA, 2008.

7. Brown, P.G.; Garver, G. Right Relationship: Building a Whole Earth Economy; Berrett Koehler: San Francisco, CA, USA, 2009.

8. Environmental economics is " $\mathrm{t}] \mathrm{he}$ branch of neoclassical economics that addresses environmental problems such as pollution, negative externalities, and valuation of nonmarket environmental services[,] focuses almost exclusively on efficient allocation, and accepts the pre-analytic vision...that the economic system is the whole, and not a subsystem of the containing and sustaining global ecosystem" ([9], p. 432).

9. Daly, H.E.; Farley, J. Ecological Economics: Principles and Applications; Island Press: Washington, DC, USA, 2004.

10. Heinzerling, L.; Ackerman, F. Law and Economics for a warming world. Harv. Law Rev. 2007, 1, $332-362$.

11. Ecological economics is " $[\mathrm{t}]$ he union of economics and ecology, with the economy conceived as a subsystem of the earth ecosystem that is sustained by a metabolic flow or 'throughput' from and back to the larger system" ([9], p. 431).

12. L'Ordre Public Ecologique/Towards an Ecological Public Order; Boutelet, M., Fritz, J.-C., Eds.; Bruylant: Brussels, Belgium, 2005.

13. Percival, R.V. Environmental law in the twenty-first century. Va. Environ. Law J. 2007, 25, 1-35.

14. Research and Degrowth. Available online: http://www.degrowth.org (accessed on 31 October 2012).

15. Martinez-Alier, J.; Pascual, U.; Vivien, F-D.; Zaccai, E. Sustainable de-growth: Mapping the context, criticisms and future prospects of an emergent paradigm. Ecol. Econ. 2010, 69, 1741-1747.

16. Latouche, S. Degrowth Economics. Le Monde Diplomatique (English edition), 14 November 2004. Available online: http://www.mondediplo.com/2004/11/14latouche (accessed on 31 October 2012).

17. Kallis, G. In defence of degrowth. Ecol. Econ. 2011, 70, 873-880.

18. Barcelona Conference on Economic Degrowth for Ecological Sustainability and Social Equity. "Degrowth bullet points" from the Barcelona conference, undated. Available online: http://www.montreal.degrowth.org/downloads/degrowth_barcelonabulletpoints.pdf (accessed on 31 October 2012).

19. Howarth, W. The progression towards ecological quality standards. J. Environ. Law 2006, 18, 3-35.

20. Kolbasov, O.S. The concept of ecological law. Conn. J. Int. Law 1989, 4, 267-277.

21. Berry, T. The Great Work: Our Way Into the Future; Three Rivers Press: New York, NY, USA, 1999.

22. Boyd, D.R. Sustainability law: (R)Evolutionary directions for the future of environmental law. J. Environ. Law Pract. 2004, 14, 357-385.

23. Bosselmann, K. The Principle of Sustainability: Transforming Law and Governance; Ashgate Publishing Co.: Burlington, VT, USA, 2008. 
24. Cullinan, C. Wild Law: A Manifesto for Earth Justice, 2nd ed.; Chelsea Green: White River Junction, VT, USA, 2011.

25. Westra, L. Ecological Integrity: Its History, Its Future and the Development of the Global Ecological Integrity Group. In Reconciling Human Existence with Ecological Integrity; Westra, L., Bosselmann, K., Westra, R., Eds.; Earthscan: Sterling, VA, USA, 2008; pp. 5-20.

26. Westra, L. An Environmental Proposal for Ethics: The Principle of Ecological Integrity; Rowman \& Littlefield Publishers: Lanham, MD, USA, 1994.

27. Rio Declaration on Environment and Development, Principle 12, 1992. Available online: http://www.unep.org/Documents.Multilingual/Default.asp?documentid=78\&articleid=1163 (accessed on18 January 2013).

28. The future we want, Outcome of the Rio+20 United Nations Conference on Sustainable Development, 2012. Available online: http://www.uncsd2012.org/content/documents/727The\%20 Future\%20We\%20Want\%2019\%20June\%201230pm.pdf (accessed on 18 January 2013).

29. United Nations Security Council. The Rule of Law and Transitional Justice in Conflict and PostConflict Societies: Report of the Secretary General; Document No. S/2004/616; United Nations: New York, NY, USA, 2004.

30. Leopold, A. A Sand County Almanac; Oxford University Press: New York, NY, USA, 1949.

31. Because ecosystems constantly evolve, it would be more consistent with current understandings of ecology to refer to the resilience, rather than stability, of the biotic community [7].

32. Nordhaus, T.; Shellenberger, M.; Blomqvist, L. The Planetary Boundaries Hypothesis: A Review of the Evidence; Breakthrough Institute: Oakland, CA, USA, 2012.

33. Heinzerling, L. Risking it all. Ala. Law Rev. 2005, 57, 155-169.

34. Victor, P.A. Managing Without Growth: Smaller By Design, Not Disaster; Edgar Elgar: Cheltenham, UK, 2008.

35. Tarlock, A.D. The future of environmental "rule of law" litigation. Pace Environ. Law Review 2000, 17, 237-272.

36. Delgado, R. Our better natures: A revisionist view of Joseph Sax's public trust theory of environmental protection, and some dark thoughts on the possibility of law reform. Vanderbilt Law Review 1991, 44, 1209-1227.

37. Naess, A. A defence of the deep ecology movement. Environ. Ethics 1984, 6, 265-270.

38. Robertson, V. Methow valley citizens. Available online: http:// www.supreme.justia.com/cases/ federal/us/490/332/case.html (accessed on 18 January 2013)

39. Kass, M.J. A NEPA climate paradox: Taking greenhouse gases into account in threshold significance determinations. Indiana Law Rev. 2009, 42, 47-96.

40. Robertson, V. On writ of certiorari to the united states court of appeals for the tenth circuit. Available online: http://www.law.cornell.edu/supct/html/03-101.ZO.html (accessed on 18 January 2013)

41. Consistent with the TMDL approach, the Great Lakes Water Quality Agreement of 1978 aims "to restore and maintain the chemical, physical, and biological integrity of the waters of the Great Lakes Basin Ecosystem" [42] and calls upon the United States and Canada to consult regarding "[t]he control of pollutant loading rates for each lake basin to protect the integrity of the ecosystem over the long term" [43]. The Agreement relies on implementation through the national 
and subnational laws of the signatories [44], along with State-to-State consultations regarding implementation [45].

42. The Great Lakes Water Quality Agreement of 1978, Article II. Available online: http://www.epa.gov/grtlakes/glwqa/1978/articles.html\#AGREEMENT\%20BETWEEN\%20CAN ADA (accessed on 18 January 2013)

43. The Great Lakes Water Quality Agreement of 1978, Article IV(3)(b). Available online: http://www.epa.gov/grtlakes/glwqa/1978/articles.html\#AGREEMENT\%20BETWEEN\%20CAN ADA (accessed on 18 January 2013).

44. The Great Lakes Water Quality Agreement of 1978, Article V. Available online: http://www.epa.gov/grtlakes/glwqa/1978/articles.html\#AGREEMENT\%20BETWEEN\%20CAN ADA (accessed on 18 January 2013).

45. The Great Lakes Water Quality Agreement of 1978, Article X. Available online: http://www.epa.gov/grtlakes/glwqa/1978/articles.html\#AGREEMENT\%20BETWEEN\%20CAN ADA (accessed on 18 January 2013).

46. Clean Water Act $\S 303(\mathrm{c})(2)(\mathrm{A})$. Available online: http://epw.senate.gov/water.pdf (accessed on 18 January 2013).

47. Clean Water Act, $\S 304(a)(1)$. Available online: http://epw.senate.gov/water.pdf (accessed on 18 January 2013)

48. Clean Water Act $\S 303(\mathrm{~d})(1)(\mathrm{C})$. Available online: Available online: http: //www. epw.senate.gov/water.pdf (accessed on 18 January 2013).

49. Clean Water Act $\S 304(a)(2)$. Available online: http://epw.senate.gov/water.pdf (accessed on 18 January 2013).

50. 40 C.F.R. $§$ 130.2(i). Available online: http://www.gpo.gov/fdsys/pkg/CFR-2011-title40vol22/pdf/CFR-2011-title40-vol22-sec130-2.pdf (accessed on 18 January 2013).

51. Convention on Long-range Transboundary Air Pollution, 30 November 1979 (entered into force 16 March 1983). Available online: http://www.unece.org/fileadmin/DAM/env/lrtap/full\% 20text/1979.CLRTAP.e.pdf (accessed on 18 January 2013).

52. Adler, R.W. Freshwater: Sustaining use by protecting ecosystems. Environ. Law Rep. 2009, 39, 10309-10315.

53. Caudill, D.S.; Curley, D.E. Strategic idealizations of science to oppose environmental regulation: A case study of five TMDL controversies. Univ. Kans. Law Rev. 2008, 57, 251-312.

54. Karr, J.R.; Yoder, C.O. Biological assessment and criteria improve total maximum daily load decision making. J. Environ. Eng. 2004, June, 594-604.

55. Umweltbundesamt. Manual on Methodologies and Criteria for Modelling and Mapping Critical Loads \& Levels and Air Pollution Effects, Risks and Trends; Umweltbundesamt: Berlin, Germany, 2004.

56. Cresser, M.S. The critical loads concept: Milestone or millstone for the new millenium? Sci. Total Environ. 2000, 249, 51-62.

57. Boyd, J. The New Face of the Clean Water Act: A Critical Review of EPA's Proposed TMDL Rule; Resources for the Future, Discussion Paper 00-12; Resources for the Future: Washington, DC, USA, 2000. Available online: http://www.rff.org/rff/Documents/RFF-DP-00-12.pdf (accessed on 18 January 2013). 
58. United States Environmental Protection Agency. Impaired Waters and Total Maximum Daily Loads? Available online: www.water.epa.gov/lawsregs/lawsguidance/cwa/tmdl/ (accessed on 29 August 2011).

59. United States Environmental Protection Agency. Withdrawal of Revisions to the Water Quality Planning and Management Regulation and Revisions to the National Pollutant Discharge Elimination System Program in Support of Revisions to the Water Quality Planning and Management Regulation, 68 Fed. Reg. 13608; United States Environmental Protection Agency: Washington, DC, USA, 2003.

60. United States Environmental Protection Agency. National Water Quality Inventory: Report to Congress, 2004 Reporting Cycle; United States Environmental Protection Agency: Washington, DC, USA, 2009.

61. Pelletier, N. Of laws and limits: An ecological economic perspective on redressing the failure of contemporary global environmental governance. Global Environ. Change 2010, 20, 220-228.

62. Spranger, T.; Hettelingh, J.-P.; Slootweg, J.; Posch, M. Modelling and mapping long-term risks due to reactive nitrogen effects: An overview of LRTAP convention activities. Environ. Pollut. 2008, 154, 482-487.

63. Gothenburg Protocol to the 1979 Convention on Long-range Transboundary Air Pollution to Abate Acidification, Eutrophication and Ground-level Ozone (30 November 1999). Available online: www.unece.org/fileadmin/DAM/env/lrtap/full\%20text/1999\%20Multi.E.Amended.2005. pdf (accessed on 18 January 2013)

64. European Union, Directive of the European Parliament and of the Council 2001/81/EC of 23 October 2001 on national emission ceilings for certain atmospheric pollutants [2001] O.J. L 309/22. Available online: http://eur-lex.europa.eu/LexUriServ/LexUriServ.do?uri= OJ:L:2001:309:0022:0030:EN:PDF (accessed on 18 January 2013).

65. Clean Air Act Title IV, Title 42, U.S. Code $\S \S 7651-76510$ (2006). Available online: http://epa.gov/oar/caa/title4.html (accessed on 18 January 2013).

66. Clean Air Act $\S$ 401(a), Title 42, U.S. Code $\S$ 7651(a) (2006). Available online: http://epa.gov/oar/caa/title4.html (accessed on 18 January 2013).

67. Reitze, A.W., Jr. The legislative history of U.S. air pollution control. Houston Law Rev. 1999, 36, 679-741.

68. Heinzerling, L. Selling pollution, forcing democracy. Stanford Environ. Law J. 1995, 14, 300-344.

69. Moore, C.A. The 1990 Clean Air Act amendments: Silk purse or Sow's ear? Duke Environ. Law Pol. Forum 1992, 26-58.

70. Doremus, H.; Hanemann, W.M. Of babies and bathwater: Why the Clean Air Act's cooperative federalism framework is useful for addressing global warming. Arizona Law Rev. 2008, 50, 799-834.

71. Jenkins, J.; Roy, K.; Driscoll, C.; Buerkett, C. Acid Rain and the Adirondacks: A Research Summary; Adirondacks Lakes Survey Corporation: Ray Brook, NY, USA, 2005. 
72. European Commission. Comparison of the EU and US Approaches towards Acidification, Eutrophication and Ground Level Ozone. In Assessment of the Effectiveness of European Air Quality Policies and Measures, 2004, Doc. B4-3040/2003/365967/MAR/C1. Available online: http://www.ec.europa.eu/environment/archives/cafe/activities/pdf/case_study1.pdf (accessed on 12 November 2012).

73. United Nations Environment Programme. Backgrounder: Basic Facts and Data on the Science and Politics of Ozone Protection, 2008. Available online: ozone.unep.org/Events/ozone_day_2008/ press_backgrounder.pdf (accessed on 29 August 2011).

74. United Nations Environment Programme, Ozone Secretariat. Handbook for the Montreal Protocol on Substances that Deplete the Ozone Layer; United Nations Environment Programme: Nairobi, Kenya, 2012. Available online: http://ozone.unep.org/Publications/MP_Handbook/MPHandbook-2012.pdf (accessed on 18 January 2013).

75. London Amendment to the Montreal Protocol, 29 June 1990 (entered into force 10 August 1992). Available online: http://ozone.unep.org/Ratification_status/london_amendment.shtml (accessed on 18 January 2013).

76. Copenhagen Amendment to the Montreal Protocol, 25 November 1992 (entered into force 14 June 1994). Available online: http://ozone.unep.org/Ratification_status/copenhagen_ amendment.shtml (accessed on 18 January 2013).

77. Montreal Amendment to the Montreal Protocol, 17 September 1997 (entered into force 10 November 1999). Available online: http://ozone.unep.org/Ratification_status/montreal_ amendment.shtml (accessed on 18 January 2013).

78. Beijing Amendment to the Montreal Protocol, 3 December 1999 (entered into force 12 February 2002). Available online: http://ozone.unep.org/new_site/en/Treaties/treaties_decisionshb.php?dec_id_anx_auto=783 (accessed on 18 January 2013).

79. Steiner, A. 20th Anniversary of the Protocol and International Day for the Preservation of the Ozone Layer, Speech at the Opening of the 19th Meeting of the Parties to the Montreal Protocol on Substances that Deplete the Ozone Layer, Montreal, 16 September 2007. Available online: www.unep.org/Documents.Multilingual/Default.asp?DocumentID=518\&ArticleID=5667\&l=en (accessed on 12 November 2012).

80. United Nations Environment Programme, Ozone Secretariat. Report of the Eleventh Meeting of the Parties to the Montreal Protocol on Substances that Deplete the Ozone Layer, 1999. Available online: ozone.unep.org/Meeting_Documents/mop/11mop/11mop-10.e.pdf (accessed 29 August 2011).

81. United Nations Environment Programme, Ozone Secretariat. Synthesis Report of the 2006 Assessments of the Scientific Assessment Panel, the Environmental Effects Assessment Panel and the Technology and Economic Assessment Panel, No. UNEP/OzL.Pro.WG.1/27/3; United Nations Environment Program: Nairobi, Kenya, 2007.

82. Roberts, M.W. The Montreal Protocol must act to prevent global climate change while restoring the ozone layer. JSDLP 2009, 9, 33-67.

83. Winchester, N.B. Emerging global environmental governance. Indiana J. Global Leg. Stud. 2009, $16,7-23$.

84. Sunstein, C.R. Worst-Case Scenarios; Harvard University Press: Cambridge, MA, USA, 2007.

85. Reeves, H. Mal de Terre; Éditions du Seuil: Paris, France, 2005. 
86. Plein, A.L. A Story between success and challenge: 20th anniversary of the Montreal Protocol. New Zeal. J. Environ. Law 2007, 11, 67-98.

87. Carpenter, S.R.; Bennett, E.M. Reconsideration of the planetary boundary for phosphorus. Environ. Res. Lett. 2011, 6, 1-12.

88. Ivanova, M. UNEP in global environmental governance: Design, leadership, location. Global Environ. Polit. 2010, 10, 30-59.

89. Yang, T.; Percival, R.V. The emergence of global environmental law. Ecol. Law Q. 2009, 36, 615-664.

90. Rees, W.E. Globalization and sustainability: Conflict or convergence? Bull. Sci. Tech. Soc. 2002, 22, 249-268.

91. Living Planet Report 2010; Pollard, D., Almond, R., Duncan, E., Grooten, M., Hadeed, L., Jeffries, B., McLellan, R., Eds.; WWF International: Gland, Switzerland, 2010.

92. Srinivasan, U.T.; Carey, S.P.; Hallstein, E.; Higgins, P.A.T.; Kerr, A.C.; Koteen, L.E.; Smith, A.B.; Watson, R.; Harte J.; Norgaard, R.B. The debt of nations and the distribution of ecological impacts from human activities. Proc. Natl. Acad. Sci. USA 2008, 105, 1768-1773.

93. Heller, M.A. The tragedy of the anticommons: Property in the transition from Marx to markets. Harvard Law Rev. 1998, 111, 621-688.

94. Foley, J.A.; Ramankutty, N.; Brauman, K.A.; Cassidy, E.S.; Gerber, J.S.; Johnston, M.; Mueller, N.D.; O’Connell, C.; Ray, D.K.; West, P.C.; et al. Solutions for a cultivated planet. Nature 2011, 478, 337-342

95. Weizsacker, E.; Desha, C.; Hargroves, K.; Stasinopoulos, P.; Smith, M. Factor Five: Transforming the Global Economy Through 80\% Improvements in Resource Productivity; Earthscan: London, UK, 2009.

96. Young, O.R; Steffen, W. The Earth System: Sustaining Planetary Life-Support Systems. In Principles of Ecosystem Stewardship: Resilience-Based Natural Resource Management in a Changing World; Folke, C., Kofinas, G.P., Chapin, F.S., Eds.; Springer Science + Business Media: New York, NY, USA, 2009; pp. 295-315.

97. Saunier, R.E.; Meganck, R.A. Dictionary and Introduction to Global Environmental Governance, 2nd ed.; Earthscan: London, UK, 2009.

98. Daly, H. Beyond Growth; Beacon Press: Boston, MA, USA, 1996.

99. Schlesinger, M.E.; Ring, M.J.; Cross, E.F. A Revised Fair Plan to Safeguard Earth's Climate. J. Environ. Protect. 2012, 3, 1330-1335.

100. Latouche, S. The Globe Downshifted, Le Monde Diplomatique (English edition), 13 January 2006. Available online: www.mondediplo.com/2006/01/13degrowth (accessed 31 October 2012).

101. Commoner, B.; Woods, P.W.; Eisl, H.; Couchot, K. Long-range Air Transport of Dioxin from North American Sources to Ecologically Vulnerable Receptors in Nunavut, Arctic Canada; Commission for Environmental Cooperation: Montreal, Canada, 2000.

102. Tarlock, A.D. Environmental law: Ethics or science. Duke Environ. Law Pol. Forum 1996, 6, 193-223.

103. Garver, G. The Rule of Ecological Law: A Transformative Legal and Institutional Framework for the Human-Earth Relationship. LLM Thesis, McGill University, Montreal, 2011. 
104. Garver, G. Introducing the Rule of Ecological Law. In Human Health and Ecological Integrity; Westra, L., Soskolne, C.L., Spady, D.W., Eds.; Routledge: New York, USA, 2012; pp. 322-334.

(C) 2013 by the authors; licensee MDPI, Basel, Switzerland. This article is an open access article distributed under the terms and conditions of the Creative Commons Attribution license (http://creativecommons.org/licenses/by/3.0/). 